\title{
Cheerleader, Opportunity Seeker, and Master Strategist: ARL Directors as Entrepreneurial Leaders
}

\section{Maria Taesil Hudson Carpenter}

\begin{abstract}
This study explores how directors of libraries with membership in the Association of Research Libraries (ARL), who are engaged in entrepreneurial leadership, define and view it. Through structured interviews and analysis of supporting documents, it examines how entrepreneurial leadership can be used as a means for creating new organizational structures, generating income, developing information delivery and technology solutions, building new partnerships, and improving services. This study has implications for library directors and administrators, organizational development specialists, and leadership trainers.
\end{abstract}

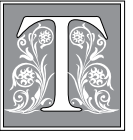

he economic recession of 2008-2009 and its aftermath have had a profound impact on higher education. Many institutions of higher education have seen a dramatic decline in their endowments: 23 percent from 2008 to 2009,1 and in fiscal year 2009, private giving dropped $\$ 2.75$ billion (or $11.9 \%$ ). ${ }^{2}$ In some instances, outstanding capital projects have been canceled or scaled back, and there has been a decline in the number of students enrolled. As a result, institutions have faced flat or shrinking budgets, combined with hiring freezes, faculty and staff furloughs, or the dropping or consolidation of academic programs. Naturally, academic libraries have not often escaped these constraints as they justify and account for expenses as a cost center, find new funding sources, form new partnerships to control costs and expand collections, and continue to engage in change management and shift to greater dissemination of digital resources.

Academic libraries may be in the process of reengineering their workforces, engaging faculty, creatively applying digital media, refining digitization programs, creating tools for data curation across disciplines, publishing digital scholarship, and integrating the latest technology with teaching and learning. ${ }^{3}$ Entrepreneurship has been a popular business term since the 1980s, and many organizations have tried to become more entrepreneurial in recent years to compete with smaller, adaptable startups. ${ }^{4}$ With much change occurring throughout many academic institutions, library directors have opportunities to use entrepreneurial leadership to transform their organiza-

Maria Taesil Hudson Carpenter is Director of Library Services for the City of Somerville, MA and a Doctoral Student of Managerial Leadership in the Information Professions program at Simmons College; e-mail: mcarpenter@somervillema.gov. The author gratefully acknowledges the comments of the journal reviewers and Judy K. Hudson. (C) Maria Taesil Hudson Carpenter 
tions to meet the changing information and service needs of users, even while under fiscal constraints.

\section{Problem Statement}

Entrepreneurial leadership is a topic of discussion in libraries, and it appears to have value as libraries cope with a changing fiscal situation. However, no study has explored how directors of libraries with membership in the Association of Research Libraries (ARL), who are engaged in entrepreneurial leadership, define and view it as a means for creating new organizational structures, generating income, developing information delivery and technology solutions, building new partnerships, and improving services. The purpose of this study is to fill that void by addressing the following questions:

1. How do they define entrepreneurial leadership?

2. What do they believe are the most important attributes of an entrepreneurial leader?

3. In what entrepreneurial activities are they engaged?

4. Why do they engage in entrepreneurial activities?

5. What factors do they perceive as barriers to and opportunities for becoming entrepreneurial?

This study furthers the understanding of entrepreneurial activities taking place at ARL libraries and of entrepreneurial leadership within a higher education setting. Additionally, it reveals what participants perceive to be the most important elements of entrepreneurial leadership: seizing opportunities, taking risks, and having a willingness to fail. This study also suggests how entrepreneurial leadership can improve finances, foster innovation, and build prestige.

\section{Literature Review Entrepreneurship}

This section is intended to provide background information to the wide and varied body of literature on entrepreneurship. A functionalist approach, developed by Schumpeter in the 1930s, established an entrepreneur as one who carries out new combinations of doing business by founding new forms of organization, developing new and cheaper sources of supply, developing novel methods of production, inventing new goods, and creating new markets. ${ }^{5}$ More recently, personal characteristics, or the "supply side of entrepreneurship" such as risk-taking, opportunity-seeking behavior, and having an entrepreneurial orientation and mindset have been studied. In 2000, Shane and Venkataraman updated and expanded the definition of an entrepreneur (see Procedures, section 1) and noted that the study of entrepreneurship includes: the sources of opportunities; the process of discovery, evaluation, and exploitation of opportunities; and the set (group) of entrepreneurs. ${ }^{6}$ Although risk taking has been designated as a characteristic of entrepreneurs, studies have not consistently shown that entrepreneurs have a risktaking propensity. ${ }^{7}$ Another characteristic, opportunity-seeking behavior, has been likened to that of a promoter - a person willing to act in a very short time frame to chase an opportunity. ${ }^{8}$ Additionally, Lumpkin and Dess found that having an entrepreneurial orientation includes "a propensity to act autonomously, a willingness to innovate and take risks, and a tendency to be aggressive toward competitors and proactive relative to marketplace opportunities." ${ }^{9}$ Whereas McGrath and MacMillan described the entrepreneurial mindset as a leadership framework that offers an action-based strategy to managers based on common characteristics of "habitual entrepreneurs."10 Entrepreneurship has also been explained as a behavioral phenomenon-the pursuit of opportunity without regard to resources currently controlled (having more than an individual set of traits and different from an economic function). ${ }^{11}$ Related to this, researchers have found that taking a strategic approach to entrepreneurship and incorporating entrepreneurial activities can improve a company's competitive 
position and profit line. ${ }^{12}$ Entrepreneurship, taken in an organizational behavior context, has been described as "a process of emergence" in which action is taken in expectation of a nonequivocal event occurring in the future. ${ }^{13}$

\section{Leadership}

Within organizations, transformational (placing a strong emphasis on followers' needs, values, morals) ${ }^{14}$ team-building (focusing on effectiveness through teambased problem solving), ${ }^{15}$ and valuebased, ethical leadership (emphasizing community, honesty, respect for others, justice, and service) ${ }^{16}$ are important leadership constructs that allow the leader to mobilize the capacity to meet the entrepreneurial challenge. ${ }^{17}$ This requires a leader who can:

1. articulate a compelling organizational vision;

2. convince others that they can accomplish goals;

3. promise that efforts will lead to extraordinary outcomes;

4. extract exceptional commitment and effort from organizational stakeholders; and

5. persevere in the face of environmental change. ${ }^{18}$

\section{Entrepreneurial Leadership}

Drawing from the work of McGrath and MacMillan; ${ }^{19}$ Kuratko and Hornsby; ${ }^{20}$ DuBrin, ${ }^{21}$ and Covin and Slevin, ${ }^{22}$ Gupta, et al. define entrepreneurial leadership as "leadership that creates visionary scenarios that are used to assemble and mobilize a "supporting cast" of participants who become committed by the vision to the discovery and exploitation of strategic value creation. ${ }^{\prime 23}$ In addition to the qualities listed in the Leadership section above, entrepreneurial leaders are committed to the development of new business opportunities while facing constraints and are willing to accept the burden of responsibility in case of failure. ${ }^{24}$ They eliminate obstacles to innovation and use their social influence to gain stakeholder support. ${ }^{25}$ They foster innovation, creativity, openness, discovery, and risk-taking ${ }^{26}$ and are intuitive and intellectually stimulated. ${ }^{27}$

\section{Intersection of Leadership Theory and Entrepreneurship}

Over the past ten years, there has been discussion of whether entrepreneurship belongs as a separate field of study or as a subset within leadership studies. ${ }^{28}$ Vecchio found that, while many of the constructs used in the study of entrepreneurship are also found within mainstream leadership theory, these findings are not beyond being incorporated within available scholarship on leadership and interpersonal influence. He believes that, until there is empirical evidence to refute these conclusions, that entrepreneurship should be viewed as a type of leadership that occurs in a specific setting. ${ }^{29}$ Cogliser and Brigham, in a comparative review of the growth and development of the fields of leadership and entrepreneurship, acknowledged that entrepreneurship is a young field with overlap in leadership especially in the areas of vision, influence, leading innovative and creative people, and planning. ${ }^{30}$ Additionally, similar to the complex development of the field of leadership, they said that much more still needed to be done in entrepreneurial studies before moving to consolidation. ${ }^{31}$ They also noted that entrepreneurship is the most rapidly growing area of the division of the Academy of Management. ${ }^{32}$

\section{An Empirical Measure of Entrepreneurial Leadership}

Gupta, MacMillan, and Surie developed a crosscultural theoretical framework of entrepreneurial leadership ${ }^{33}$ from three major bodies of leadership theory:

1. neocharismatic/transformational theory, in which leaders who appeal to the higher needs of followers for self-actualization and personal values motivate them; ${ }^{34}$

2. leader-member exchange theory, in which leaders elicit heightened 
levels of group participation among team members; ${ }^{35}$ and

3. value-based leadership, in which leaders articulate, appeal, and convey confidence in realizing vision and mission. ${ }^{36}$

The entrepreneurial leader adapts to an ever-changing environment and encourages followers to abandon the conventional and commit to entrepreneurial action. $^{37}$

Gupta et al. tested their framework using the instrument employed in the Global Leadership and Organizational Behavior (GLOBE) survey, an extensively validated study of leadership that included 62-society crosscultural samples of over 15,000 middle managers from all over the world. With a few exceptions, they found that respondents universally perceived entrepreneurial leadership attributes to be effective. ${ }^{38}$ They began with 23 leadership attributes related to entrepreneurial behaviors, but they excluded four attributes (risk-taking, autonomous, independent, and self-interested) because they had a low positive or negative correlation with the remaining attributes; in essence, they are not as universally accepted as the other attributes. They then classified the remaining 19 attributes into five roles (see Discussion, Definition section). ${ }^{39}$

\section{Literature of Library and Information \\ Science}

Few authors have written on this topic in the literature of library and information science, beyond Neal, who calls for academic library directors to be entrepreneurial by innovatively seeking out new business opportunities as a way of addressing contingencies or constraints while in the pursuit of excellence. ${ }^{40} \mathrm{He}$ outlines a typology of entrepreneurship for academic libraries, which includes the following elements:

- Market-based, customized delivery and packaging of information. This includes competitive ventures that meet the needs of library and information service consumers.
- Center for research and design. Offer experimental labs for creation, production, marketing, distribution, and archiving of information products and new technologies.

- Innovative applications of technology. For instance, libraries act as competitors in the information technology marketplace.

- Faculty, university, industry partnerships. Work with partners toward new product creation, innovative service models, or experimental design.

- E-commerce. Create new business ventures based on e-commerce models.

- Lab for experimentation in teaching and learning. Expand research and development in pedagogy.

- Publishing ventures. Call for academic libraries to become major players in emerging new publishing ventures to build a new economic framework for scholarly communications.

- Technology transfer. Bring new knowledge from research and development to the market.

Advancing the digital library is at the core of Neal's entrepreneurial vision. This includes "leveraging the content, reshaping the organizational culture, building the physical and expertise infrastructure, setting the direction, and then just doing it." ${ }^{41}$

\section{Procedures}

As of September 2009, of the then 123 ARL libraries, 94 were U.S.-based university libraries that had a director who was not interim. ${ }^{42}$ For one of those directors to be a possible study participant, that person must have met at least one of the following criteria:

- Written on the topic of entrepreneurship, defined as discovering, evaluating, and exploiting opportunities for creating goods and services, ${ }^{43}$ or entrepreneurial leadership, defined as the ability to envisage and create a scenario of possible challenges that are enacted by followers and backed by stakeholders. ${ }^{44}$ 
- Gained national recognition for directing a library that is known for its entrepreneurial activities or approaches; recognition refers to conference presentations on entrepreneurship identified via lists, Web sites, or by word-of-mouth (from directors to the investigator).

The investigator asked a panel (Adam Corson-Finnery, former director of special initiatives, University of Pennsylvania Libraries; Steven Bell, associate university librarian for research and instructional services, Temple University; and Camila A. Alire, dean emerita, University of New Mexico and Colorado State University, and past president of the American Library Association) to review the set of criteria. They recommended no changes and then reviewed the list of directors that the investigator identified for possible inclusion. They made additions and deletions to the list. In addition, at the conclusion of the actual interviews, using the snowball method of nonprobability sampling, the investigator asked participants for the names of any additional directors they perceived as meeting the criteria. The investigator shared those names with the panel and asked if they merited inclusion. If the panel agreed, those directors were included.

From November 2009 through March 2010, the investigator conducted structured telephone interviews with the directors. A structured interview is a technique "in which evaluators ask the same questions of numerous individuals or individuals representing numerous organizations in a precise manner, offering each interviewee the same set of possible responses." ${ }^{45}$ The structured interviews involved the use of critical incident, asking interviewees to reflect on a recent situation in which they applied entrepreneurial leadership (e.g., developing the work-force, creating alternative funding sources, facing external competitors, collaborating with faculty on interdisciplinary projects and translational research, or advancing the digital library). Interviewees were asked to report on specific observable incidents that demonstrate entrepreneurial leadership behavior. (The appendix reprints the data collection instrument.)

The interviews were audio-recorded and transcribed. The investigator then applied content analysis, "a research technique for making replicable and valid inferences from texts (or other meaningful matter) to the contexts of their use," ${ }^{\prime 6}$ to the responses to the interview questions and to any documents the interviewees provided. The interview transcripts and documents were analyzed and coded.

Once Simmons College's IRB granted approval, the investigator asked participants to sign a consent form prior to the interview. Permission to record the session was also requested at the start of the interview. Each interviewee was given a number that was used to associate responses instead of identifying the interviewee's name or institution. Summaries of the transcript were shared with the interviewees, who reviewed and validated content.

\section{Findings}

Of the eleven directors invited to participate who met all criteria, eight did so. Three never responded to the invitation to participate.

\section{Emergence of a Definition}

The participants were given a definition of entrepreneurial leadership drawn from Gupta et al. ${ }^{47}$ and $\mathrm{Neal}^{48}$ and were asked to comment on its component parts and to make any suggested changes (see the Appendix for the text of the definition that participants were given).

Three directors said that the original definition described leadership in general. One of them stated, "The definition includes all good things to be able to do and you can have entrepreneurial leaders who do only some of these things and you can have leaders who do most of these things and are not entrepreneurial at all." Two directors suggested the 
definition was too long. Two thought it was accurate, and two wanted inspirational leadership added. Other proposed changes included replacing the word "challenges" with "opportunities," adding risk-taking, and making sure that creating infrastructure to support entrepreneurial activities was also part of the definition. There was disagreement about whether collective activity belonged in the definition.

\section{Attributes}

Participants were asked to add attributes that they associate with entrepreneurial leadership or delete any they do not, from Gupta et al., ${ }^{49}$ McGrath and MacMillan, ${ }^{50}$ Neal, ${ }^{51}$ Tarabishy et al., ${ }^{52}$ and Van Zyl and Mathur-Helm..$^{53}$

They did not delete any but they did add the following:

- has ability to develop effective partnerships;

- has ability to inspire and develop shared vision;

- has ability to read signals of others and interpret human behavior;

- has courage ("You've got to be willing to fail and have some mechanism for dealing with it.");

- has curiosity ("The greatest opportunities come from being curious -if you are not curious, you won't have opportunities.");

- has patience;

- has perseverance; and

- thinks through, is comfortable with, and manages complex situations and environments. ("It is important for entrepreneurial leaders to be comfortable with the messiness of complexity.")

From the list of attributes included in table 1 , they were then asked to rate the importance of each one on a scale of one to five, one being the least important and five being the most important. The investigator calculated the median for each attribute and, as table 1 indicates, the attributes groups of those receiving medians of 5, 4.5, $4,3.5$, and 3 . The top-rated attributes are takes calculated risks; encourages innovativeness, openness, and discovery; seizes opportunities; and is strategically oriented and can formulate strategy based on available resources. On the other hand, the lowest-rated attributes are has ability to execute, has bargaining ability, perseveres in the face of change, and understands how technology is used.

Table 2 includes the most important attributes $(\mathrm{Mdn}=5$ top tier; $\mathrm{Mdn}=4.5 \mathrm{sec}-$ ondary tier, $\mathrm{Mdn}=4$ tertiary tier) rated by participants and the additional attributes participants would like to have included (suggested). One way to make sense of attributes is to cluster them by characterization. The investigator created four clusters that are also included in table 2: business orientation, leadership, emotional intelligence, and research orientation. The business orientation cluster focuses on attributes related to creating business, such as is strategically oriented or seizes opportunities. The leadership cluster focuses on attributes connected with leadership theory, such as has a confidence-building approach. Closely related to leadership is the emotional intelligence cluster, which includes has ability to read signals of others and interpret human behavior. The research orientation cluster includes attributes closely associated with research, such as is intellectually stimulated and questions assumptions.

\section{Entrepreneurial Activities in ARL Libraries}

Directors noted entrepreneurial activities taking place locally and in other ARL libraries. To preserve the anonymity of the participants, table 3 provides examples grouped by thematic area. These are examples that directors mentioned as occurring at other institutions. Across all major thematic areas, the examples offer new approaches in management and often try to solve a problem, such as finding ways to generate new income, addressing information technology needs, or improving services. Several of the examples focus on framing new roles for libraries, including providing dataset preservation and curation services, taking expanded roles in scholarly publishing, and offering 
copyright expertise. Twelve of 18 of the examples that the directors mentioned include a partnership component. Seed or project funding, either self-funded through library administration or funded via external sources, is important to seven projects or programs.

In several of the examples, the library director saw an opportunity for further development and seized it. Some respondents said that the examples given could very well fail. Some respondents also said that the initiatives they highlighted were part of broader strategic directions, such as to build and expand their institution's publishing capacity, to get buy-in from senior administration, or to embark on more collaborative collection development.

\section{Barriers}

Participants shared three major barriers to becoming entrepreneurial: the people

\begin{tabular}{|c|c|}
\hline \multicolumn{2}{|l|}{$\begin{array}{c}\text { TABLE } 1 \\
\text { Attributes of Entrepreneurial Leaders }\end{array}$} \\
\hline Attribute & Median \\
\hline Takes calculated risks & 5 \\
\hline Encourages innovativeness, openness, and discovery & 5 \\
\hline Seizes opportunities & 5 \\
\hline Is strategically oriented and can formulate strategy based on available resources & 5 \\
\hline $\begin{array}{l}\text { Has ability to allocate resources effectively toward the creation of new business } \\
\text { models }\end{array}$ & 4.5 \\
\hline Has ability to motivate others through shared vision & 4.5 \\
\hline Has ethical practice & 4.5 \\
\hline Has foresight/intuition & 4.5 \\
\hline Questions assumptions & 4.5 \\
\hline $\begin{array}{l}\text { Has ability to allocate resources effectively toward the creation of new business } \\
\text { models }\end{array}$ & 4 \\
\hline Has path-clearing ability & 4 \\
\hline Has a confidence-building approach & 4 \\
\hline Has a decisive, positive mindset & 4 \\
\hline Is intellectually stimulated & 4 \\
\hline Patiently seeks new opportunities in a selective manner & 4 \\
\hline Has pattern recognition & 4 \\
\hline Shoulders the burden of responsibility in case of failure & 4 \\
\hline Has social influence & 4 \\
\hline Carries out new combinations of doing business & 3.5 \\
\hline Has control of resources and the ability to leverage other people's resources & 3.5 \\
\hline Has creativity & 3.5 \\
\hline Has a team-building, collaborative approach & 3.5 \\
\hline Has ability to execute & 3 \\
\hline Has bargaining ability & 3 \\
\hline Perseveres in the face of change & 3 \\
\hline Understands how technology is used & 3 \\
\hline
\end{tabular}


around them, a change-resistant organizational culture and structure, and lack of funding. People, however, were the most frequently mentioned barrier. If colleagues are unwilling to change, are afraid of failure and criticism, or do not believe that it is a role of the library to be entrepreneurial, the leader will be challenged to enact an entrepreneurial approach. Additionally, even if people embrace entrepreneurship, they may lack project management abilities, which can hinder the translation of entrepreneurial vision into action. Authority figures can also act as a barrier by not allowing the library director to try something new and fail. This finding is supported by organizational change literature. ${ }^{54}$

Organizational culture that is resistant to change and hierarchical organizational

\begin{tabular}{|c|c|c|c|}
\hline \multicolumn{4}{|c|}{$\begin{array}{c}\text { TABLE } 2 \\
\text { Top and Suggested Entrepreneurial Leadership Attributes by Type }\end{array}$} \\
\hline Business orientation & Leadership & $\begin{array}{l}\text { Emotional } \\
\text { intelligence }\end{array}$ & $\begin{array}{c}\text { Research } \\
\text { orientation }\end{array}$ \\
\hline $\begin{array}{l}\text { Is strategically oriented } \\
\text { and can formulate } \\
\text { strategy based on } \\
\text { available resources } \\
\text { Top tier }\end{array}$ & $\begin{array}{l}\text { Encourages } \\
\text { innovativeness, } \\
\text { openness, and discovery } \\
\text { Top tier }\end{array}$ & $\begin{array}{l}\text { Has foresight/ } \\
\text { intuition } \\
\text { Secondary tier }\end{array}$ & $\begin{array}{l}\text { Questions } \\
\text { assumptions } \\
\text { Secondary tier }\end{array}$ \\
\hline $\begin{array}{l}\text { Seizes opportunities } \\
\text { Top tier }\end{array}$ & $\begin{array}{l}\text { Has ability to motivate } \\
\text { others through shared } \\
\text { vision } \\
\text { Secondary tier }\end{array}$ & $\begin{array}{l}\text { Has social influence } \\
\text { Tertiary tier }\end{array}$ & $\begin{array}{l}\text { Is intellectually } \\
\text { stimulated } \\
\text { Tertiary tier }\end{array}$ \\
\hline $\begin{array}{l}\text { Takes calculated risks } \\
\text { Top tier }\end{array}$ & $\begin{array}{l}\text { Has ethical practice } \\
\text { Secondary tier }\end{array}$ & $\begin{array}{l}\text { Has path-clearing } \\
\text { ability } \\
\text { Tertiary tier }\end{array}$ & $\begin{array}{l}\text { Has pattern } \\
\text { recognition } \\
\text { Tertiary tier }\end{array}$ \\
\hline $\begin{array}{l}\text { Has a decisive, positive } \\
\text { mindset } \\
\text { Tertiary tier }\end{array}$ & $\begin{array}{l}\text { Has a confidence- } \\
\text { building approach } \\
\text { Tertiary tier }\end{array}$ & $\begin{array}{l}\text { Has ability to } \\
\text { develop effective } \\
\text { partnerships } \\
\text { Suggested }\end{array}$ & $\begin{array}{l}\text { Has curiosity } \\
\text { Suggested }\end{array}$ \\
\hline $\begin{array}{l}\text { Patiently seeks new } \\
\text { opportunities in a } \\
\text { selective manner } \\
\text { Tertiary tier }\end{array}$ & $\begin{array}{l}\text { Shoulders the burden of } \\
\text { responsibility in case of } \\
\text { failure } \\
\text { Tertiary tier }\end{array}$ & $\begin{array}{l}\text { Has ability to read } \\
\text { signals of others } \\
\text { and interpret human } \\
\text { behavior } \\
\text { Suggested }\end{array}$ & \\
\hline \multirow{3}{*}{$\begin{array}{l}\text { Has ability to allocate } \\
\text { resources effectively } \\
\text { toward the creation of } \\
\text { new business models } \\
\text { Tertiary tier }\end{array}$} & $\begin{array}{l}\text { Has courage } \\
\text { Suggested }\end{array}$ & & \\
\hline & $\begin{array}{l}\text { Is comfortable } \\
\text { with and manages } \\
\text { complex situations and } \\
\text { environments } \\
\text { Suggested }\end{array}$ & & \\
\hline & $\begin{array}{l}\text { Has patience } \\
\text { Suggested }\end{array}$ & & \\
\hline
\end{tabular}




\begin{tabular}{|c|c|}
\hline \multicolumn{2}{|c|}{$\begin{array}{c}\text { TABLE } 3 \\
\text { Examples of Entrepreneurial Activities in ARL Libraries }\end{array}$} \\
\hline $\begin{array}{l}\text { Shared } \\
\text { management }\end{array}$ & $\begin{array}{l}2 C U L \text {. A collaboration between Cornell University and Columbia } \\
\text { University that integrates resources, collections, services, and } \\
\text { expertise between two library systems (see http://2cul.org/). }\end{array}$ \\
\hline $\begin{array}{l}\text { Expanded global } \\
\text { partnerships }\end{array}$ & $\begin{array}{l}\text { Memo of Understanding. Cornell University and Tsinghua University } \\
\text { in Beijing have signed a memo of understanding that includes and } \\
\text { goes beyond staff training and information exchange to imagining the } \\
\text { sharing of scholarly resources, professional networks, and support for } \\
\text { joint collection building, services, research library theory and practice, } \\
\text { and software research and design. }\end{array}$ \\
\hline \multirow[t]{2}{*}{$\begin{array}{l}\text { Experimentation } \\
\text { with new ways to } \\
\text { generate income }\end{array}$} & $\begin{array}{l}\text { Espresso book machines. Libraries including the University of } \\
\text { Michigan, University of Pittsburgh, and University of Utah have } \\
\text { implemented or are in the process of implementing a book-making } \\
\text { machine that can print on demand. }\end{array}$ \\
\hline & $\begin{array}{l}\text { Business ventures and partnerships committee and innovation grants. } \\
\text { The University of Utah Libraries has a staff committee that looks at } \\
\text { new ways of doing business and partners with the business school. } \\
\text { Also, an innovation and program enrichment grant program provides } \\
\$ 20,000 \text { seed money to staff for experimentation each year. }\end{array}$ \\
\hline \multirow{2}{*}{$\begin{array}{l}\text { New } \\
\text { management } \\
\text { approach to } \\
\text { research tools }\end{array}$} & $\begin{array}{l}\text { Avery Index to Architectural Literature. This database recently } \\
\text { returned to being under Columbia University's management, and they } \\
\text { are building, expanding, and enhancing its publishing capacity. }\end{array}$ \\
\hline & $\begin{array}{l}\text { arXiv.org. Led by Cornell University, partners are planning an open- } \\
\text { access model in which the top } 200 \text { institutional users worldwide can } \\
\text { make voluntary contributions to provide support for the project. }\end{array}$ \\
\hline \multirow[t]{3}{*}{ New solutions } & $\begin{array}{l}\text { HathiTrust. Established in } 2008 \text { by thirteen universities of the } \\
\text { Committee on Institutional Cooperation (CIC), the University of } \\
\text { California system, and the University of Virginia to archive and share } \\
\text { their digitized collections and to make them available for researchers } \\
\text { and the public (if works are in the public domain). }\end{array}$ \\
\hline & $\begin{array}{l}\text { Google Books Project. Many research libraries have partnered with } \\
\text { Google Books to digitize locally owned collections and to make out- } \\
\text { of-copyright books and public domain works available to the public. } \\
\text { Additionally, the CIC is partnering with Google to digitize up to } 10 \\
\text { million volumes of important legacy collections across its member } \\
\text { libraries. }\end{array}$ \\
\hline & $\begin{array}{l}\text { Integration with collaboration and learning environment. With funding } \\
\text { from the Andrew W. Mellon Foundation, Indiana University Bloomington } \\
\text { Libraries and University of Michigan Library are developing open-source } \\
\text { software tools to integrate access to library-licensed digital content within } \\
\text { the Sakai collaboration and learning environment. }\end{array}$ \\
\hline \multirow[t]{2}{*}{$\begin{array}{l}\text { Emergence of } \\
\text { new units and } \\
\text { human capital }\end{array}$} & $\begin{array}{l}\text { Center for Digital Research and Scholarship. An eighteen-person unit } \\
\text { at Columbia works with faculty and researchers to apply technology in } \\
\text { innovative ways to their research and publishing activities. }\end{array}$ \\
\hline & $\begin{array}{l}\text { Copyright Advisory Office. This office offers guidance and educational } \\
\text { services to help the Columbia University community address } \\
\text { copyright issues. This is one of the first copyright offices to be part of } \\
\text { a research library in the United States. }\end{array}$ \\
\hline
\end{tabular}


TABLE 3 (continued)

\section{Examples of Entrepreneurial Activities in ARL Libraries}

\begin{tabular}{|c|c|}
\hline \multirow[t]{2}{*}{$\begin{array}{l}\text { Emergence of } \\
\text { new units and } \\
\text { human capital }\end{array}$} & $\begin{array}{l}\text { Entrepreneurial Library Program. The Johns Hopkins University } \\
\text { Library system has a seven-person department that creates innovative } \\
\text { products and services such as an alumni database. This department is } \\
\text { fully self-sustaining. }\end{array}$ \\
\hline & $\begin{array}{l}\text { Building a unified publishing environment. University of Michigan } \\
\text { is now managing the university press and is creating a Web-based } \\
\text { publication model, publishing textbooks and journals, and running } \\
\text { open-access experiments. }\end{array}$ \\
\hline $\begin{array}{l}\text { Fresh approaches } \\
\text { to planning }\end{array}$ & $\begin{array}{l}\text { The University of Minnesota Libraries changed its approach to } \\
\text { planning to educate staff about the complexity of a particular area and } \\
\text { to assign responsibility to a group of people to help articulate related } \\
\text { strategies. Well-known experts were brought in to present on emergent } \\
\text { themes and helped to frame issues and set directions. They met with } \\
\text { library staff and with senior administrators on campus. }\end{array}$ \\
\hline \multirow[t]{2}{*}{$\begin{array}{l}\text { Partnering with } \\
\text { scientists }\end{array}$} & $\begin{array}{l}\text { David Conservancy. This Johns Hopkins University project aims to } \\
\text { acquire, preserve, and make accessible large datasets, primarily in the } \\
\text { sciences and social sciences. It received } \$ 20 \text { million in funding from } \\
\text { the NSF and seed money from Microsoft and the Institute of Museum } \\
\text { and Library Services (IMLS). The partnership was initiated when an } \\
\text { astronomer who was developing a database of data asked how the } \\
\text { library could help with preservation. }\end{array}$ \\
\hline & $\begin{array}{l}\text { Data curation and cyber-infrastructure development. This new unit } \\
\text { at the University of California, San Diego (UCSD) is a partnership } \\
\text { between the libraries and the supercomputer center. The unit is } \\
\text { pushing functionality of high-end computational functions to all } \\
\text { faculty members. It received two million dollars in funding from } \\
\text { the Library of Congress, through the National Digital Information } \\
\text { Infrastructure and Preservation program (NDIIP). }\end{array}$ \\
\hline \multirow[t]{2}{*}{$\begin{array}{l}\text { Enhancing the } \\
\text { user experience }\end{array}$} & $\begin{array}{l}\text { Digital signage with campus security. UCSD Libraries partnered with } \\
\text { the campus security office to acquire sixty plasma screens that allow the } \\
\text { library to display security broadcasts as well as library-specific messages. }\end{array}$ \\
\hline & $\begin{array}{l}\text { Anthropological research. Researchers at the University of } \\
\text { Rochester's River Campus have used anthropological and } \\
\text { ethnographic methods to discover how undergraduate students study } \\
\text { and write papers and to find out how the library related to their } \\
\text { academic needs. Additionally, they have studied the work practices of } \\
\text { faculty to build a better institutional repository. }\end{array}$ \\
\hline
\end{tabular}

structures were also mentioned as hindrances to entrepreneurship. Academic libraries typically have hierarchical structures. Often these structures include staff reporting to supervisors and managers, managers reporting to administrators, and administrators reporting to directors and deans. This structure has historically made sense, as libraries have been in the business of organizing and preserving books and other information sources since their inception, and frequent checkpoints, approvals, and detailed workflows have helped libraries to excel in their missions. These measures, however, can impede entrepreneurial action such as seizing opportunities. Strategies to address these barriers may include different approaches 
to planning, as in the case of the University of Minnesota, or having an entrepreneurial arm, such as at Johns Hopkins University and Columbia University.

Lack of funding was another factor mentioned that prevents entrepreneurial action. "Resource development has been an interesting and [is] an important barrier to entrepreneurial action," said one participant. If directors have ready access to funds for experimentation or can allocate part of the budget for taking chances on new ideas, entrepreneurship can take root and flourish. Without those resources it is much more difficult to take risks and experiment. Another director, however, challenged this, saying, "I would be far more likely to take on a new project that wasn't funded in anticipation that it would demonstrate what the library is capable of and then generate the funding."

\section{Opportunities and Support for Entrepreneurship}

Participants shared factors that helped support entrepreneurial activities. The most frequently mentioned enabler of entrepreneurial activity was the people around the directors. These include mentors and inspiring leaders whom they work alongside. Some participants said that the opportunities to be entrepreneurial grew out of stretch assignments handed to them by mentors. One participant said that the entrepreneurial opportunity came from a mentor who helped to clear paths where there were obstacles. Other directors said that the idea of entrepreneurial action was formed while working alongside leaders who offered a broader perspective of how to do work. Respondents also said that being around motivated, talented staff who wanted to follow the vision of their leadership also helped to foster entrepreneurial action.

The second most frequently mentioned enabler of entrepreneurship was a supportive organizational culture and structure where the entrepreneurial spirit was fostered and entrepreneurial activities encouraged. Having a workplace that is free of administrative micromanagement allowed autonomy for directors. Funding for experimentation also fostered entrepreneurship, as did leadership development programs such as the UCLA senior fellows program and ARL leadership programs. One director shared, "You make your own opportunities, I think." This is an example of an individual who saw a problem, seized the opportunity, and developed solutions.

\section{Why Engage in Entrepreneurial Activities and Approaches?}

Participants' reasons for being entrepreneurial fell into three areas: to (1) improve the financial management, (2) foster innovation, and (3) build prestige. Participants said that being entrepreneurial was helping their libraries to address financial difficulties and to attract new resources. Additionally, taking an entrepreneurial approach to planning enabled some directors to redirect existing resources toward new, emerging needs and to "frame new roles for libraries or new arenas for those roles." Being entrepreneurial has helped them to eliminate redundancy, increase efficiency, and focus librarianship on what human capital can do that can't be done by some other means. Further, entrepreneurial approaches have enabled directors to exploit opportunities before they disappear. Directors also said that being entrepreneurial fosters innovation; for example, a director said that our best thinking and best ideas come from when we are being playful in our approach. Additionally, other directors said that being entrepreneurial enables them to be more competitive and distinguish their organizations.

\section{Discussion}

Participants believe that entrepreneurial leadership is important, especially the elements of risk-taking and allowing failure to happen, as well as finding, seizing, and exploiting opportunities.

\section{Definition}

Gupta et al. noted two interrelated challenges for entrepreneurial leaders: 
1. a scenario enactment: "envisaging and creating a scenario of possible opportunities that can be seized to revolutionize the current transaction set given resource constraints," and

2. a cast enactment: convincing potential followers and stakeholders that the execution of this transaction set is possible by assembling resources, including creating the right mix of people, to accomplish the objectives related to the scenario. ${ }^{55}$

Study participants confirmed both challenges in the definition but distilled and simplified them to envisage and to enact, because the directors do not express either component in terms of scenario and cast enactments but do speak of visioning and motivating others to take action.

Four of Gupta et al.'s five roles adapted from McGrath and MacMillan ${ }^{56}$ for the entrepreneurial leader were supported: framing the challenge (pushing the team to the limits of its abilities without pushing it over the limits), absorbing uncertainty (taking the burden of responsibility for the future), path-clearing (negotiating opposition and clearing the path for scenario enactment), and building commitment (building an inspired common purpose and team); the fifth role, specifying limits, was not supported. Based on study results, framing was modified to communicating the purpose and need to change; absorbing uncertainty was changed to accepting failure; and path-clearing and building commitment were confirmed and remained the same. Although evidence for Gupta et al.'s adapted roles existed in all but one category, study participants described their roles differently, as cheerleader, opportunity seeker, and master strategist.

Based on comments from participants, several changes to the original entrepreneurial leadership definition were made. The definition was shortened, as several participants said that it was too long, but the following components were added: envisaging and finding; building partnerships and fostering experimentation and play; and creating infrastructure to foster innovation. Creating infrastructure relates to the importance of making a strategic commitment to new business development so that team members are committed to seeking out new opportunities. ${ }^{57}$

Although it was intended that one new definition would emerge from the interviews, there was a strong difference of opinion about the importance of collective activity. Therefore, two new entrepreneurial leadership definitions emerged; only one emphasizes collective action. These definitions consist of the following text, one with and one without the bracketed phrase:

Entrepreneurial leadership is the ability to envisage, find, seize, and exploit opportunities. Entrepreneurial leaders accomplish this by identifying and inspiring talent [to take collective action around shared vision] and by minimizing obstacles for this talent. Additionally, they build partnerships, raise resources, foster experimentation and play, encourage risk-taking, accept failure, and communicate the purpose and need for change. Entrepreneurial leaders also create infrastructure to foster innovation, including new ways or combinations of providing services and building new business models.

\section{Self-described Roles: Cheerleader, Opportunity Seeker, and Master Strategist}

Participants described their roles in entrepreneurial activities primarily as cheerleader and conveyor of vision, opportunity seeker, and master strategist. As number-one cheerleader and conveyor of vision, the entrepreneurial leader pushes, advocates for, encourages, and supports staff. Directors view it as their responsibility to keep spirits lifted and to bolster the courage to try. The entrepreneurial leader recognizes and communicates the need for innovation and change and 
encourages staff to implement change. The leader persuades people that they can do things differently from the ways they have been done.

Seeing and seizing opportunities that others do not see was also a role expressed by participants. One director described his leadership style as "principled opportunism" - one in which he grabs chance opportunities that align with his guiding principles. He said there is a window of opportunity and sometimes it is better to do something, even if it is not optimal. Seizing opportunities was the second most frequently discussed part of the definition and a top-ranked attribute. Of perceived roles, seizing opportunities most closely connects with the definition and the ranked attributes results.

A third role was that of master strategist. This includes conceptualizing, writing, framing, eliminating obstacles, getting support from stakeholders, and asking questions through continual examination. One director thought that it is the role of the leader to continually assess, figure out what is not working, and lead the team to come up with solutions. A director observed that Susan Gibbons, of the University of Rochester, and her team members were brilliant strategists for the types of advances they made in student learning by asking questions, looking at patterns, and designing solutions. Another participant noted that it was his role to build organizational understanding and commitment to business planning for sustainability in new areas. Additionally, another director suggested that in this role the leader needs to determine what is the ethos of an institution-what is truly valued. The master strategist role is most closely linked to the top-ranking attribute is strategically oriented and can formulate strategy based on available resources; this role is also connected to creating infrastructure to foster innovation in the revised definitions.

Other self-described roles were raiser of monetary resources and project leader or primary investigator, especially on grant applications. The need to raise resources was one of the top reasons given for being entrepreneurial. Additionally, roles noted by the directors were eliminator of obstacles and clearer of paths, obtainer of support from stakeholders, and identifier of talent. One director described her role as "creating the environment to do things." Another director said that it was his role to "identify a few people who have the ability to see the future, obtain support, and then get obstacles out of the way." Participants' self-described roles resonate with the revised definitions and list of key attributes.

\section{Evidence of Neal's Typology}

The study results show that, since Neal's call for academic libraries to enact an entrepreneurial imperative, ${ }^{58}$ activities have occurred within his typology. It is striking, however, that although 11.7 percent of library directors from qualifying ARL institutions met the entrepreneurialrelated criteria for inclusion in this study, 88.3 percent did not. While many entrepreneurial examples were named-including faculty and global partnerships, experimentation with ways to generate income, new technology solutions and products, and publishing ventures - they were connected with 17 institutions. This reveals that a core group of ARL libraries are doing several entrepreneurial projects (see table 3 for descriptions of some of these activities).

The following components could be added to Neal's original typology: ${ }^{59}$ shared management, as seen in 2CUL; global partnerships, as demonstrated in the Cornell and Tsinghua University collaboration; and infrastructure supportive of entrepreneurship in the areas of planning, innovation incentives, and restructuring the organization. Changing the structures to encourage opportunityseeking directly relates to the strategic commitment to new business development that Gupta et al. identified. ${ }^{60}$ Additionally, a proposed amendment to Neal's typology is to replace e-commerce with 
new business models for generating income, because no examples of e-commerce were given, yet several examples of methods to potentially generate resources were. Additionally, with the emergence of the new technology units at Columbia, Johns Hopkins, and UCSD, the center for research and design could be broadened to build infrastructure supportive of entrepreneurship.

\section{Attributes}

Two of the most discussed components of the definition aligned with the top-ranking attributes. The most agreed-upon part of the definition was risk-taking and accepting failure $(87.5 \%)$, which corresponded with one of the top-ranked attributes, takes calculated risks. Participants (75\%) also emphasized finding, seizing, and exploiting opportunities. This corresponded with another of the top-ranked attributes, seizes opportunities. Although developing partnerships was a point that most directors spoke about and cited examples of in the entrepreneurial activities section (for instance, 2CUL, HathiTrust, and arXiv.org), absent from the definition and the attribute list was any mention of building effective partnerships. Based on this information, the ability to develop effective partnerships should be added to the attribute list, as was suggested by one participant, and to the definition, as was suggested by several participants. Alignment of risk-taking and accepting failure and the seizing of opportunities in two major sections of the study helps to validate these components of entrepreneurial leadership. Similarly, the emphasis on partnerships throughout the study findings validates the addition of this component to the idea of entrepreneurial leadership.

\section{Culture Clash: Innovation versus Protecting Core Services and Ethical Practice}

Several directors spoke of a tension between the old and new ways of doing business, between protecting core services and breaking the mold. One director discussed the importance of ensuring cultur- al firewalls - of building new approaches and strategies without sacrificing core services, values, or ethical practice. Another director said of this clash between traditional ways of working versus new approaches, "It is essential to get people out of their old habits and make people think about ways they would not have thought before - to change culture and thinking." The struggle to shift from a cost recovery model to a for-profit model was expressed, as well as how to support and provide open access yet offer fee-based services. Another related tension that was discussed is the recognition of the need for and the challenge of building play space into the structure of the organization. Creating and fostering experimentation requires a different mindset and way of organizing library work, which traditionally has been highly structured and hierarchical. One director stated there was a pull between protecting intellectual property rights and providing unfettered access to a broad constituency, because "a democracy really needs and relies upon that access."

Directors are also struggling with the notion of offering income-generating services and products in what has traditionally been a nonprofit world. The common space of information resources has customarily been available to users at a low cost, or the costs have been hidden from users. Library directors are very aware of all of these tensions and are being challenged to address them across the rapidly changing information services landscape. These struggles all speak to a broader tension in research libraries that are trying to bridge traditional roles with new roles as users' information-seeking behaviors and ways of learning continue to change in a networked, global environment. One director sums it up:

[There is] an internal struggle for directors about what libraries have been, and what they need to become, and how to protect unfettered access. And to keep to core 
values - libraries are in the business of providing value that cannot be obtained anywhere else, that is critical to whatever core business of the enterprise - in universities - that is provoking thought.

\section{Divergence on Collective Activity versus Individual Action}

The element of entrepreneurial leadership that caused the most disagreement was the idea of collective activity versus individual action. Three directors discussed the importance of taking a collective approach to being entrepreneurial, including leveraging and stretching talent for collective action, fostering group decision-making, and practicing a collaborative style of leadership toward shared purpose. In a divergent view, one director posited that inclusiveness and teambuilding do not lead to innovation or being entrepreneurial and that he is "dubious about a collective spirit of innovation." This director believes it is unusual for teams to make breakthroughs because only a few entrepreneurial thinkers exist within any organization. Another director said that sometimes consensus building is not possible, so it should not be assumed in the definition. All who took a position on collective activity versus individual action were quite adamant about their views. This divergence in opinion is the reason two amended definitions of entrepreneurial leadership came out of this study.

\section{Importance of Risk-taking, Courage, and Failure}

Seven of the eight directors discussed the importance of taking risks and allowing failure to happen. Directors shared that the organizational structure and culture should foster risk-taking. "Real elements of being entrepreneurial are taking risks and failing, and these elements should be part of the whole environment rather than a source of blame," said one director. Directors also spoke of the courage it takes to lead into unknown and risky territory. Another participant stated it this way: "The willingness to put yourself in a position where you might get whacked is something that you learn in part by having gotten whacked. You've got to be willing to fail and have some mechanism for dealing with it." Several participants expressed that directors need to, as one director put it, "get in there and find something new ...then exploit." These findings differ from the GLOBE study. Evidently, taking risks is a behavior that is deemed effective only in some organizations and societies and is not part of a universal view of entrepreneurial leadership.

\section{Experience Drives Perceptions and Multiple Approaches Work}

Personal experience and preferred leadership styles shape participants' perceptions about entrepreneurial leadership. For example, a director who had worked for the federal government and unions found that deliberation, teamwork, and collective action were inhibitors to entrepreneurship. He said, "It is very rare that teams make breakthroughs." For the director who discovered that "not all partners are created equally," seizing opportunities and forming the "right" strategic partnerships have become key factors to being entrepreneurial. He learned this after working with partners who could not carry their end of the partnership. For the director who emphasizes inspirational leadership, important aspects of entrepreneurial leadership include a commitment to teambuilding, creating a shared sense of purpose, and motivating followers. Another director shared that she tries to learn from situations that irritate her and to remove them as a potential barrier to other people. Finally, another director's preferred style is conceptual-she recognizes that it is native to how she works. She believes that concept comes before action and she will spend a lot of time conceiving an idea and writing about it before having her team act on it.

For the participant who had worked for the federal government, it is imperative that an entrepreneurial leader take 
responsibility when things fail. He went on to say that people are often fearful of change, because they ultimately fear failure and blame. He said that, in government, if you try something and fail, you have to go to Congress and explain why. In contrast, in private institutions, there is no such thing as failed research, because learning always takes place. However, another director believes that shouldering responsibility is inconsequential for an entrepreneur but that it is very important for a true leader. He said that he has known a lot of narcissistic yet effective individuals who never accepted blame for anything but kept generating good ideas. This director added, "I've known a lot of university presidents who don't accept responsibility for what goes wrong and have done really quite well for leading their institutions. Nobody likes them very well, but that is a different matter."

Shifting away from personal experience, he offered observations of differing approaches to entrepreneurial leadership. The first is the "bull in a china shop" approach in which people get together, brainstorm and throw out ideas, and see if there is a business model that can take shape. The second is the "all ducks and dots lined up" approach in which a masterful plan is created and then executed. He said this is the approach in which one would carefully eliminate obstacles and obtain support. Directors shared many approaches to being an entrepreneurial leader. Whether one takes a "bull in a china shop" or "ducks and dots" approach, or emphasizes teambuilding versus individual action, varied approaches work for participants.

\section{The People Around Are Critical to Entrepreneurship}

Participants said that the people around them have been paramount in encouraging or discouraging entrepreneurship. Working with mentors and visionary leaders who pushed mentees and cleared obstacles, supportive colleagues who fostered experimentation and offered broader perspectives, and motivated, talented followers has fostered entrepreneurial activity. Conversely, an expressed barrier was working with people who are averse to change or the notion of libraries as being entrepreneurial, supervisors who said no to experimentation and risk-taking, and staff who cannot manage projects or handle criticism. These findings signify that library directors should surround themselves with people who will continue to push them and broaden their perspectives of how to lead and manage. Directors should also mentor and challenge others to be entrepreneurial.

\section{Significance of Partnerships}

All of the directors emphasized the importance of building and managing effective partnerships. This includes developing partnerships with portions of the commercial sector, such as the information technology industry. One director said that libraries must "get comfortable with the 'uncomfortableness' of public/ private collaborations." Other important partners include those from campus and peer organizations. One participant noted that libraries need leaders who have the ability to work across venues and cultures to build new approaches, break molds, and operate differently without violating principles and ethics. Another director recognized that the ecosystem is global and cross-sector. Various paths to partnerships were described, including through friendships, serving on committees, projects falling into their laps, and having people come to them with a problem, or seeing a problem and drawing in others to tackle it. The emphasis on partnerships highlights the imperative to build networks to tap into when opportunities arise and to encourage staff to do this, too. As libraries partner with the for-profit industry, questions loom. Will these partnerships help libraries to be entrepreneurial over the long haul? As libraries seize opportunities for collaboration, should they be concerned with competing with these forprofit business partners in the delivery of information discovery and access? 


\section{Gains Made by Being Entrepreneurial}

In addition to raising resources such as winning grant funding, directors spoke of gained visibility in the information and technology communities and the elevation of the prestige of the library on campus in the eyes of high-level administrators such as the provost and president, as well as of prominent faculty members. One director shared that by hiring scientists to conduct basic research, he was able to present the notion that the library is undertaking research in its own domain. "This has just elevated the role of the library on campus in a way that would never have happened if we hadn't seen what the coin of the realm was here, which was actually doing research." Additionally, libraries have been able to innovatively develop solutions to problems, discover new knowledge, and reallocate resources through such efforts as the 2CUL partnership, the Google Books digitization project, and the anthropological studies at the University of Rochester.

ARL libraries have made significant strides incorporating new technologies, creating new business models, and conducting research in the areas of teaching and learning. Have they gone far enough? One participant argues that research libraries have not yet built a deep, rigorous research and development capacity, nor have they generated and applied enough new knowledge to improve libraries. Challenges will continue to be amplified as traditional United States-based universities are navigating the changing landscape of higher education, including the proliferation of for-profit programs, the globalization of education, and segmentation of faculty researcher and teacher roles.

\section{Future Courses of Action}

As libraries continue to transform, often under fiscal constraints and pressure to be distinctive, and as they bridge old modes of work with new models, entrepreneurial leadership offers an approach in which directors envisage, find, seize, and exploit opportunities. Directors interested in pursing entrepreneurial leadership might review, customize, and incorporate the following possible courses of action that have arisen out of this study. These include approaches in human resource management, organizational structure and planning, and leadership and communication.

\section{Human Resource Management}

This study shows that several potential strategies for supporting entrepreneurship exist in the human resource management arena. Directors can hire entrepreneurs and business people with a start-up mentality and an entrepreneurial mindset to help seize opportunities and develop new business models. In this case, the organizational structure will need to be adjusted to accommodate and support any new such hires. Learning activities, practice assignments, discussions, and rewards and recognition programs can encourage staff to face fears and take risks. Additional training in and adoption of a specific project management system will help to increase efficiency and effectiveness of projects.

\section{Organizational Structure and Planning}

In addition to creating the organizational structure to recruit and hire entrepreneurial types (and using accepted human resource training and development methods to develop employees' entrepreneurial leadership skills), entrepreneurial units can be created to encourage experimentation and play. Additionally, a percentage of staff time can be designated for research and development or experimentation. Creative exercises can also be integrated into meetings. Furthermore, featured programs and services that address challenges (such as making the leap to incomegenerating services while providing core research and instruction services) can demonstrate the translation of concept to action for staff and stakeholders.

Related to planning, library managers can build formal and informal networks 
of potential partners. Recognizing that some managers do this already, the system for building partnerships can be expanded or shored up to be more strategic. For example, if a strategic priority is focusing on building tools for data preservation and acquisition in medical ethics, the library director may want to hold high-level meetings with academics, librarians, and technical specialists at other institutions who are also addressing this critical need. This will not only position the library to seize partnership opportunities as they arise but also be at the forefront of chosen priority issues. Additionally, the value and expectation of being entrepreneurial can be conveyed to staff in vision statements, planning documents, informal messaging, job descriptions, and individual learning plans.

\section{Leadership and Communication}

Directors can model courageous behavior and discuss and demonstrate overcoming fears. This might be communicated oneon-one, through talks given to staff and the academic community, in writings, and informal chats. Directors can also catch self-tendencies to be an administrative barrier ("get out of the way") and to clear barriers for staff doing entrepreneurial work. Additionally, they can reinforce to staff that failure is part of the game and model accepting failure when it happens-showing it as an opportunity for continued growth. Directors can point to and celebrate examples of entrepreneurship - both lessons learned and successes. Directors can also challenge talented staff members to be entrepreneurial and to reward and recognize staff when entrepreneurial action takes place. By taking these actions, directors will reinforce and model the value of and support for entrepreneurial leadership.

\section{Topics for Further Research}

It may be useful to survey the directors of ARL libraries who did not meet the entrepreneurial criteria to find out if they believe it would be advantageous to learn more about and incorporate this leadership framework. This may have implications for leadership trainers and those doing organizational development work. It may also be instructive to interview study subjects in a few years to learn how successfully they and their organizations were implementing entrepreneurial leadership. Extending this study to directors of public libraries, non-ARL academic libraries, and ARL member libraries in Canada and comparing the results would illuminate differences and similarities in approaches and activities. Additionally, comparisons with directors in other countries and executives of companies known to be innovative could be instructive because their visions of entrepreneurship may be different or similar to those of library directors. Vision statements, structures supporting innovation, and employee attitudes could be compared and contrasted to give further insight into how entrepreneurial leadership could help organizations to realize their missions. A tangential topic that emerged as a research need in this study is how project management skills are developed and success measured. This could also be useful to managers as they address change in service, collections, and the way staff work.

\section{Conclusion}

Entrepreneurial leadership is helping some academic research library directors to foster change and to remove barriers to innovation. The study exposes that a lot of work can be done in the areas of organizational development and human resource management to support entrepreneurial action and that leaders can model and communicate the value of entrepreneurial leadership. Although research findings have demonstrated mixed support for risk-taking as a characteristic of entrepreneurial leadership, the results of this study show strong support for it. The elements of entrepreneurial leadership and the proposed courses of action can be used to assist libraries in their endeavors to improve finances, 
build prestige, and foster innovation. Entrepreneurial leadership is a framework that empowers library directors to take risks, seize opportunities, and accept failure-to fulfill organizational teaching and learning missions. Entrepreneurial leadership principles may help more library directors as they address new challenges in the rapidly changing setting of higher education and information management.

\section{Appendix: Interview Questions}

Thank you very much for your time. This interview should take approximately thirty minutes. Do you have the confirmation note readily available? If not, I can e-mail you another copy. If you don't have e-mail readily available, I will prompt you throughout the session. Please just ask me to repeat anything you wish to hear again.

Can you please refer to the definition provided of entrepreneurial leadership, which comes from a framework connecting entrepreneurship and leadership concepts identified in business and library literature.

Definition: Entrepreneurial leadership is the ability to envisage and create a scenario of possible challenges that are enacted by followers and backed by stakeholders. Entrepreneurial leaders accomplish this by seeking and exploiting opportunities in the face of change, carrying out new combinations of doing business, motivating followers to go beyond what they thought possible; shouldering the burden of responsibility in case of failure; eliminating obstacles and obtaining support from stakeholders; building commitment through team-building and encouraging a collective spirit of innovation, creativity, openness, and discovery; specifying limits and sustaining commitments to new business development in the face of contingencies or constraints; questioning assumptions; and personal modeling of the above qualities and behaviors.

1. You have been identified as someone who is an entrepreneurial leader. In what ways are you? or are you not?

2. How would you expand or refine this definition to explain entrepreneurial leadership?

3. Please refer to the list of attributes of entrepreneurial leadership.

3 a. On a scale of $1-5$, with 1 being the least important and 5 being the most important attribute of entrepreneurial leadership, can you please rate each as I read it:

\begin{tabular}{|l|}
\hline Is strategically oriented and can formulate strategy based on available resources \\
\hline Seizes opportunities \\
\hline Carries out new combinations of doing business \\
\hline Has a positive, decisive mindset \\
\hline Has a confidence-building approach \\
\hline Has bargaining ability \\
\hline Has a team-building, collaborative approach \\
\hline Has creativity \\
\hline Is proactive \\
\hline Has foresight/intuition \\
\hline
\end{tabular}




\begin{tabular}{|l|}
\hline Has pattern recognition \\
\hline Takes calculated risks \\
\hline Has social influence \\
\hline Patiently seeks new opportunities in a selective manner \\
\hline Has ability to execute \\
\hline Has ability to allocate resources effectively toward the creation of new business models \\
\hline Has control of resources and the ability to leverage other people's resources \\
\hline Questions assumptions \\
\hline Has ability to motivate others through shared vision \\
\hline Perseveres in the face of change \\
\hline Shoulders the burden of responsibility in case of failure \\
\hline Is intellectually stimulated \\
\hline Has path-clearing ability \\
\hline Understands how technology is used \\
\hline Has ethical practice \\
\hline Encourages innovativeness, openness, discovery \\
\hline
\end{tabular}

3b. What, in your opinion, is the most important attribute?

3c. Least important attribute?

3d. Any other attributes you would add to the list?

4a. Please describe a situation over the past year in which your organization has taken an entrepreneurial approach. Follow-up questions:

b. What were the activities and steps you undertook?

c. Why did you choose this approach?

d. What was your role?

e. What were your results?

f. Any lessons learned?

g. What about this approach was useful?

h. How effective was this approach?

5a. Please reflect back on your leadership development. What barriers did you face to becoming an entrepreneurial leader?

$5 b$. What opportunities did you have?

6. What entrepreneurial approaches are you aware of that are being taken at other ARL libraries?

7. Do you have any more reflections on entrepreneurial leadership that you would like to share?

\section{Notes}

1. Goldie Blumenstyk, "Average Return on Endowment Investments Is Worst in Almost 40 Years," Chronicle of Higher Education, 5 February 2010, A22-23.

2. Kathryn Masterson, "Private Giving to Colleges Dropped Sharply in 2009," Chronicle of Higher Education, 12 February 2010, A24-25.

3. Council on Library and Information Resources, No Brief Candle: Reconceiving Research Libraries for the 21st Century (Washington, D.C.: Council on Library and Information Resources, 2008). Available online at www.clir.org/pubs/reports/pub142/pub142.pdf [accessed 18 May 2010].

4. Howard H. Stevenson, "A Perspective on Entrepreneurship," HBS No. 9-384-131 (Boston: 


\section{Cheerleader, Opportunity Seeker, and Master Strategist 31}

Harvard Business School Publishing, 2006).

5. Joseph A. Shumpeter, The Theory of Economic Development (New York: Oxford University Press, 1961).

6. Scott Shane and S. Venkataraman, "The Promise of Entrepreneurship as a Field of Research," The Academy of Management Review 25, no. 1 (2000): 217-26.

7. Robert P. Vecchio, "Entrepreneurship and Leadership: Common Trend and Common Threads," Human Resource Management Review 13 (2003): 303-27.

8. Stevenson, "A Perspective on Entrepreneurship," 5.

9. G.T. Lumpkin and Gregory G. Dess, "Clarifying the Entrepreneurial Orientation Construct and Linking Iit to Performance," Academy of Management Review 21, no. 1 (1996): 135-72.

10. Rita Gunther McGrath and Ian MacMillan, The Entrepreneurial Mindset: Strategies for Continuously Creating Opportunity in an Age of Uncertainty (Boston: Harvard Business School Press, 2000).

11. Stevenson, "A Perspective on Entrepreneurship."

12. Donald F. Kuratko and Jeffrey S. Hornsby, "Corporate Entrepreneurial leadership for the 21st Century," Journal of Leadership Studies 5, no. 2 (1998): 27-39; Vipin Gupta, Ian C. MacMillan, and Gita Surie, "Entrepreneurial Leadership: Developing and Measuring a Cross-Cultural Construct," Journal of Business Venturing 19 (2004): 241-260.

13. William B. Gartner, Barbara J. Bird, and Jennifer A. Starr, "Acting as If: Differentiating Entrepreneurial from Organizational Behavior," Entrepreneurship, Theory and Practice (Spring 1992): 13-31.

14. James MacGregor Burns, Leadership (New York: Harper \& Row, 1978).

15. Stephen J. Zaccaro, Andrea L. Rittman, and Michelle A. Marks, "Team Leadership," Leadership Quarterly 12 (2001): 451-83; J.R. Hackman and Richard E. Walton, "Leading Groups in Organizations," in Designing Effective Work Groups, ed. P.S. Goodman \& Associates (San Francisco, Calif.: Jossey-Bass, 1986): 72-119.

16. Burns, Leadership; Peter G. Northouse, Leadership Theory and Practice (Calif.: Sage, 2007), $341-70$.

17. Gupta, MacMillan, and Surie, “Entrepreneurial Leadership," 243.

18. Ibid.

19. McGrath and MacMillan, The Entrepreneurial Mindset.

20. Kuratko and Hornsby, "Corporate Entrepreneurial Leadership for the 21st Century."

21. Andrew J. DuBrin, Leadership: Research Findings, Practice, and Skills (New York: Houghton Mifflin Company, 2004).

22. Jeffrey G. Covin and Dennis P. Slevin, "Strategic Management of Small Firms in Hostile and Benign Environments," Strategic Management Journal 10, no. 1 (1989): 75-87.

23. Gupta, MacMillan, and Surie, "Entrepreneurial Leadership," 241-60.

24. Kim B. Clark, Robert H. Hayes, and Christopher Lorenz, The Uneasy Alliance: Managing the Productivity-Technology Dilemma. (Boston: Harvard Business School Press, 1985).

25. Gupta, MacMillan, and Surie, "Entrepreneurial Leadership," 247.

26. Claudia C. Cogliser and Keith H. Brigham, "The Intersection of Leadership and Entrepreneurship: Mutual Lessons to Be Learned," The Leadership Quarterly 15 (2004): 771-99; Vecchio, "Entrepreneurship and Leadership," 307.

27. Gupta, MacMillan, and Surie, “Entrepreneurial Leadership," 250.

28. Vecchio, "Entrepreneurship and Leadership," 303-07.

29. Ibid., 322-23.

30. Cogliser and Brigham, "The Intersection of Leadership and Entrepreneurship," 777-80.

31. Ibid., 771-99.

32. Ibid., 790.

33. Gupta, MacMillan, and Surie, "Entrepreneurial Leadership," 246-49.

34. Bernard M. Bass, Leadership and Performance beyond Expectations (New York: Free Press, 1985); Burns, Leadership.

35. George B. Graen and James F. Cashman, "A Role-Making Model of Leadership in Formal Organizations: A Developmental Approach," in Leadership Frontiers, ed. James G. Hunt and Lars L. Larson (Kent, Ohio: Kent State University Press, 1975): 143-65; George B. Graen and Mary UhlBien, "Relationship-Based Approach to Leadership: Development of Leader-Member Exchange (LMX) Theory of Leadership over 25 Years: Applying a Multi-Level Multi-Domain Perspective," The Leadership Quarterly 6 (1995): 219-47.

36. Jay A. Conger and Rabindra N. Kanungo, "Toward a Behavioral Theory of Charismatic Leadership in Organizational Settings," The Academy of Management Review 12, no. 4 (1987): 637-47; Robert J. House and Ram N. Aditya, "The Social Scientific Study of Leadership: Quo Vadis?" Journal of Management 23, no. 3 (1997): 409-73.

37. Gupta, MacMillan, and Surie, "Entrepreneurial Leadership," 245-46. 
38. Ibid., 256-57.

39. Ibid., 249-51.

40. James G. Neal, "Entrepreneurial Imperative," portal: Libraries and the Academy 1, no. 1 (2001): 1-13.

41. Ibid., 4 .

42. *For the purposes of this study, the word director also applies to those libraries that have a dean or university librarian instead of a director.

43. Cogliser and Brigham, "The Intersection of Leadership and Entrepreneurship," 771-99; Scott Shane and S. Venkataraman, "The Promise of Entrepreneurship as a Field of Research," The Academy of Management Review 25, no. 1 (2000): 217-26.

44. Shane and Venkataraman, "The Promise of Entrepreneurship as a Field of Research"; Gupta, MacMillan, and Surie, "Entrepreneurial Leadership"; McGrath and MacMillan, The Entrepreneurial Mindset.

45. U.S. General Accounting Office, Using Structured Interviewing Techniques (Washington, D.C.: U.S. General Accounting Office, 1991), 11. Available online at http://archive.gao.gov/t2pbat7/144388.pdf [accessed 17 March 2010].

46. Klaus Krippendorff, Content Analysis: An Introduction to Its Methodology (Thousand Oaks, Calif.: Sage Publications, 2004), 18.

47. Gupta, MacMillan, and Surie, "Entrepreneurial Leadership."

48. Neal, "Entrepreneurial Imperative," 4.

49. Gupta, MacMillan, and Surie, "Entrepreneurial Leadership."

50. McGrath and MacMillan, The Entrepreneurial Mindset.

51. Neal, "Entrepreneurial Imperative."

52. Tarabishy, Solomon, Fernald, and Sashkin, "Entrepreneurial Leader's Impact."

53. Hendrik J.C. Van Zyl, and Babita Mathur-Helm, "Exploring a Conceptual Model, Based on the Combined Effects of Entrepreneurial Leadership, Market Orientation and Relationship Marketing Orientation on South Africa's Small Tourism Business Performance," South African Journal of Business Management 38, no. 2 (2007): 17-24.

54. James E. Post and Barbara W. Altma, "Managing the Environmental Change Process: Barriers and Opportunities," Journal of Organizational Change Management 7, no. 4 (1988): 64-81.

55. Gupta, MacMillan, and Surie, "Entrepreneurial Leadership," 256-57.

56. McGrath and MacMillan, The Entrepreneurial Mindset.

57. Ibid., 256.

58. Neal, "Entrepreneurial Imperative."

59. Ibid.

60. Gupta, MacMillan, and Surie, “Entrepreneurial Leadership,” 256. 